\title{
Population development of Drosophila suzukii (Matsumura) (Diptera: Drosophilidae) in vineyards of Çanakkale Province ${ }^{1}$
}

\author{
Çanakkale ili üzüm bağlarında Drosophila suzukii (Matsumura) (Diptera: \\ Drosophilidae)'nin popülasyon gelişmesi
}

\author{
Ismail KASAP ${ }^{*}$
}

\section{Eray ÖZDAMAR ${ }^{2}$}

\begin{abstract}
The spotted wing drosophila, Drosophila suzukii (Matsumura) (Diptera: Drosophilidae), is one of the important invasive pests of cultivated berry and stone fruits worldwide. The purpose of this study was to determine the population growth of $D$. suzukii in vineyards in Çanakkale Province from 2014 to 2017. The numbers of $D$. suzukii male and female individuals caught in the bait traps were recorded weekly. Drosophila suzukii population started to emerge from late September to February in all years. The maximum population of $D$. suzukii in the 2014-2015 sampling period was recorded on 29 November and 13 December 2014 at 153 individuals. In the 2015-2016 and 2016-2017 sampling periods, the maximum populations were 103 and 141 individuals recorded on 12 and 4 December, respectively. The results indicated that the $D$. suzukii population increased in the Çanakkale Province in three sampling years during November and December. These results are important as they provide information useful for the control of $D$. suzukii in vineyards in this province.
\end{abstract}

Keywords: Çanakkale, Drosophila suzukii, population development, vineyard, Turkey

\section{Öz}

Kanadı noktalı sirke sineği, Drosophila suzukii (Matsumura) (Diptera: Drosophilidae) dünyada meyve üretim alanlarında üzümsü ve çekirdekli meyvelerin önemli istilacı zararılıarından biridir. Bu çalışma ile 2014 ve 2017 yılları arasında Çanakkale ilindeki üzüm bağlarında $D$. suzukiỉnin popülasyon gelişiminin belirlenmesi amaçlanmıştır. Örneklemeler 2014-2017 yılları arasında yem tuzakları kullanılarak haftada bir olacak şekilde yürütülmüştür. Tuzaklardan toplanan $D$. suzukii erkek ve dişi bireylerinin sayıları haftalık olarak sayılarak kaydedilmiştir. Üç yıl boyunca, D. suzukii popülasyonu eylül ayında ortaya çıkmaya başlamış ve şubat ayında sonlanmıştır. 2014-2015 örnekleme periyodunda $D$. suzukii popülasyonu, 29 Kasım ve 13 Aralık 2014 tarihlerinde toplam 153 erkek ve dişi birey ile en yüksek yoğunluğa ulaşmıştır. 2015-2016 ve 2016-2017 örnekleme döneminde, 12 Aralık ve 4 Aralık tarihlerinde sırası ile toplam 103 ve 142 birey olarak popülasyonun tepe noktasına ulaşı̆̆ı saptanmıştır. Bu çalışmalar sonucunda D. suzukii' nin popülasyonunun Çanakkale ilinde kasım sonu ile aralık aylarında en yüksek noktaya ulaştığını göstermiştir. Çanakkale ili bağ alanlarında $D$. suzukiïnin mücadele zamanı hakkında bir fikir vermesi açısından bu sonuçlar oldukça önemlidir.

Anahtar sözcükler: Çanakkale, Drosophila suzukii, popülasyon gelişmesi, üzüm bağı, Türkiye

\footnotetext{
1 This study was presented as an oral presentation at the VII. Turkish Plant Protection Congress with International Participation (1417 November 2018, Muğla, Turkey).

${ }^{2}$ Çanakkale Onsekiz Mart University, Faculty of Agriculture, Department of Plant Protection, 17020 Çanakkale, Turkey

* Corresponding author (Sorumlu yazar) e-mail: ikasap@comu.edu.tr

Received (Alınış): 19.12.2018Ａccepted (Kabul ediliş): 09.02.2019 


\section{Introduction}

The worldwide increase in agricultural product trade with the advancement of international trade and technology has resulted in many invasive species rapidly spreading beyond their original range (Baser et al., 2015, 2018). Spotted wing drosophila, Drosophila suzukii (Matsumura) (Diptera: Drosophilidae), from South Asia (India and Bangladesh), which has attracted significant attention as an invasive species in recent years, was first recorded as a pest of cherry (Prunus spp.) in Japan (Kanzawa, 1939). It was first found to have spread beyond its original range during the 1980s reaching Hawaii followed by North America (California, USA) and South America causing economic losses in fruits such as cherry, grape, peach and strawberry (Hauser, 2011). It was first recored in the Europe in Spain and Italy in 2008 (Raspi et al., 2011; Walsh et al., 2011; Calabria et al., 2012; Cini et al., 2014; Depra et al., 2014). Drosophila suzukii in now known to causes economic losses on stone fruits and berry fruits, such as blackberry, grape, mulberry, raspberry and strawberry (Beers et al., 2011; Bruck et al., 2011; Goodhue et al., 2011; Lee et al., 2011; Cini et al., 2012; Yu et al., 2013; Stewart et al., 2014; loriatti et al., 2015; Ögür et al., 2018).

Drosophila suzukii was first recorded in Turkey in August 2014 in strawberry in Erzurum Province (Orhan et al., 2016). It was then recorded during observations on fly species causing damage in Çanakkale Province in September 2014 in vineyards after which related studies were started (Özdamar \& Kasap, 2017; Kasap \& Özdamar, 2017).

The most important characteristic that distinguishes $D$. suzukii from other Drosophilidae species is its ability to oviposition during the pre-ripening period of the fruit with saw-shaped oviposition tubes (Baser et al., 2015; Ögür et al., 2018). The failure to detect infested fruits during and after the harvest period, hatching of the larvae after the harvest period, feeding on fruit tissue thereby damaging the fruit tissue and secondary infections (fungi and bacteria) in wounds inflicted during oviposition result in a decrease in marketable fruit, shortened shelf life and significant economic losses (Bolda et al., 2010; Walsh et al., 2010; Orhan et al., 2016; Önder et al., 2016; Tozlu et al., 2016; Ögür et al., 2018).

Çanakkale Province is an important area in Turkey for table and wine grape, and cherry production. Wine grape production in Turkey was $370 \mathrm{kt}$ in 2004 , increasing by $64 \%$ to $488 \mathrm{kt}$ in 2017 . Likewise, cherry production was $245 \mathrm{kt}$ in 2014, increasing by about 2.5 times to $627 \mathrm{kt}$ in 2017 (Anonymous, 2017). When production for the past 13 years is taken into consideration, the scale of potential damage that could be caused by $D$. suzukii cannot be ignored. Therefore, the purpose of this study was to determine the population development of $D$. suzukii in Çanakkale Province to help in minimizing the potential impact of this pest and to provide a baseline for future studies.

\section{Material and Methods}

\section{Detection of Drosophila suzukii and field studies}

The studies started in Çeşmealtı and Gümüşçay in Biga District of Çanakkale Province in August 2014 by hanging bait traps in vineyards for detecting $D$. suzukii. After the pest was detected, three vineyards were also selected in Çeşmealtı and Gümüşçay. Eight bait traps consisting of apple cider vinegar, wine and pure water were placed in each vineyard on 15 August. Observations were made weekly with trapped flies counted and placed in $70 \%$ ethanol. The traps were renewed every $15 \mathrm{~d}$ and data collection continued until the end of February 2017. The bait mixture (about $150 \mathrm{ml}$ ) was placed in $1.5 \mathrm{~L}$ plastic bottles with seven to eight holes of about $0.5 \mathrm{~cm}$ made in the upper half of the bottles as entry points for the flies (Figure 1). The traps were attached to the vines using wire ties. 


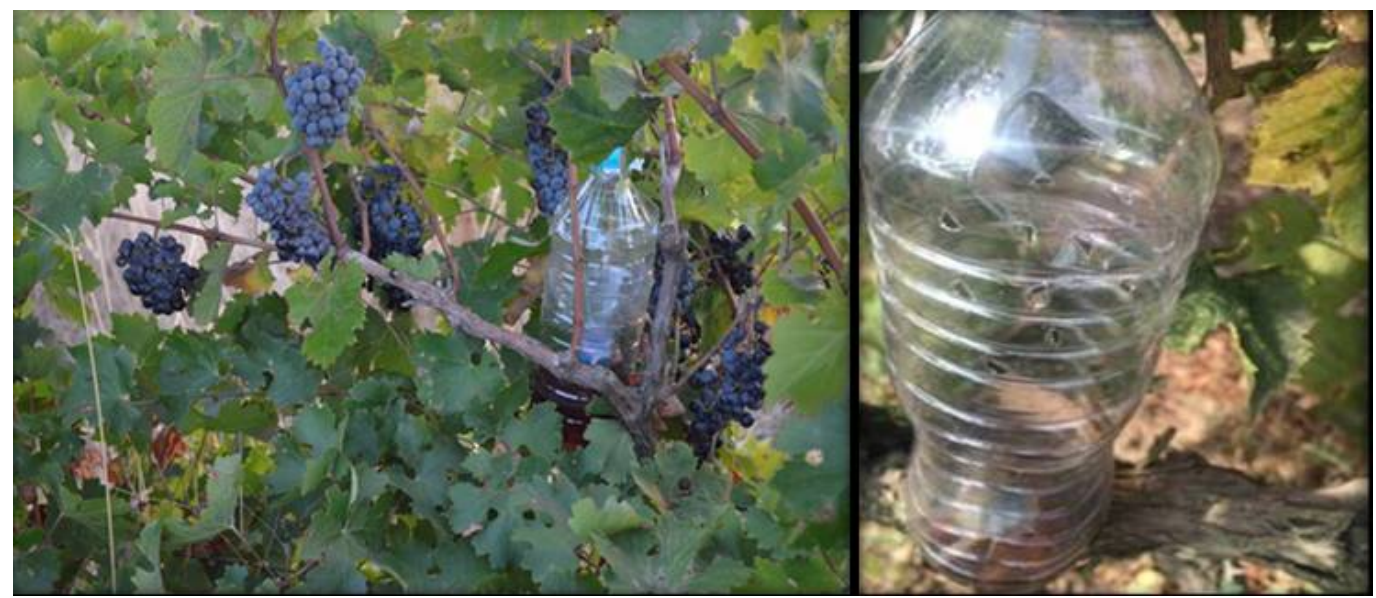

Figure 1. Bait traps in the gardens to capture Drosophila suzukii.

\section{Laboratory studies}

The bait traps were collected weekly and brought to the ÇOMU Faculty of Agriculture Plant Protection Department Acarology Laboratory where the adult flies were collected using a sieve and then examined under a stereo microscope and gender recorded.

\section{Results and Discussion}

The first $D$. suzukii male individual was detected on 13 September 2014. The adult population continued to increase after this date and the highest number recorded was 153 individuals/trap on 29 November and 13 December 2014. The adult flies caught in the traps decreased from the end of December till the end of January. No adult flies were caught in the traps after that (Figure 2). A total of 1037 individuals were caught in all traps during 2014-2015 consisting of 514 females and 533 males. In 2015-2016, the traps were deployed on 30 August 2015 and the first $D$. suzukii adults were caught on 27 September (3ㅇ and $1{ }^{\lambda}$ ). The number of adults caught in the traps increased after that date reaching 103 individuals/trap on 6 December. A total of 649 individuals were caught in all traps during 2015-2016 consisting of 303 females and 361 males (Figure 2). In 2016-2017, the traps were deployed in August with the first adults caught on 25 September ( 19 and $2 \hat{\gamma})$. The number of adults caught in the traps increased after that date reaching 141 individuals/trap on 4 December. On 11 December, 124 individuals/trap were caught on 11 December and the population continued to decrease after that date. A total of 11 individuals/trap were caught on 29 January. No adults were caught after that (Figure 2). A total of 767 individuals were caught in all traps during 2016-2017 consisting of 370 females and 397 males. The female:male ratio was to be about $1: 1$ in all years (Figure 2).

The results showed that $D$. suzukii appeared in Çanakkale Province vineyards in mid-September, increasing during October and November, peaking in December and declining in January. Harvesting starts in Çanakkale Province vineyards in October. The increase of $D$. suzukii population after this date indicates that the pest feeds on fruit remaining in or near the vineyard and continues its life cycle by feeding on fruit such as nectarine and plum. It was found that $D$. suzukii may complete 15 generations/year under suitable conditions, with each cycle lasting about $10 \mathrm{~d}$ and remains active throughout the year under suitable conditions. It has also been reported that $D$. suzukii may feed on both ripe and unripe fruit particularly on apricot, blackberry, blueberry, cherry, peach, strawberry and other berry fruits (Anonymous, 2012). Baser et al. (2015) reported that $D$. suzukii populations continue throughout the year in southern Italy due to the suitable temperature and moisture, feeding on hosts such as blackberry, fig, grape, jujube, plum and rose hip, and reaching their maximum number in December. Orhan et al. (2016) reported D. suzukii in the Erzurum Province in August and September 2014 in strawberry fruit. Emiljanowicz et al. (2014) reported that $D$. suzukii lives for about $86 \mathrm{~d}$ at $22^{\circ} \mathrm{C}$ and $25 \% \mathrm{RH}$, with the longest life span of $154 \mathrm{~d}$. They also report that females lays about 5.7 eggs/d totaling about 636 eggs over their entire life span. Also, the female:male ratio was about $1: 1$ and the net reproduction rate of a female $\left(r_{m}\right.$ value) was 0.179 females/female/d. 

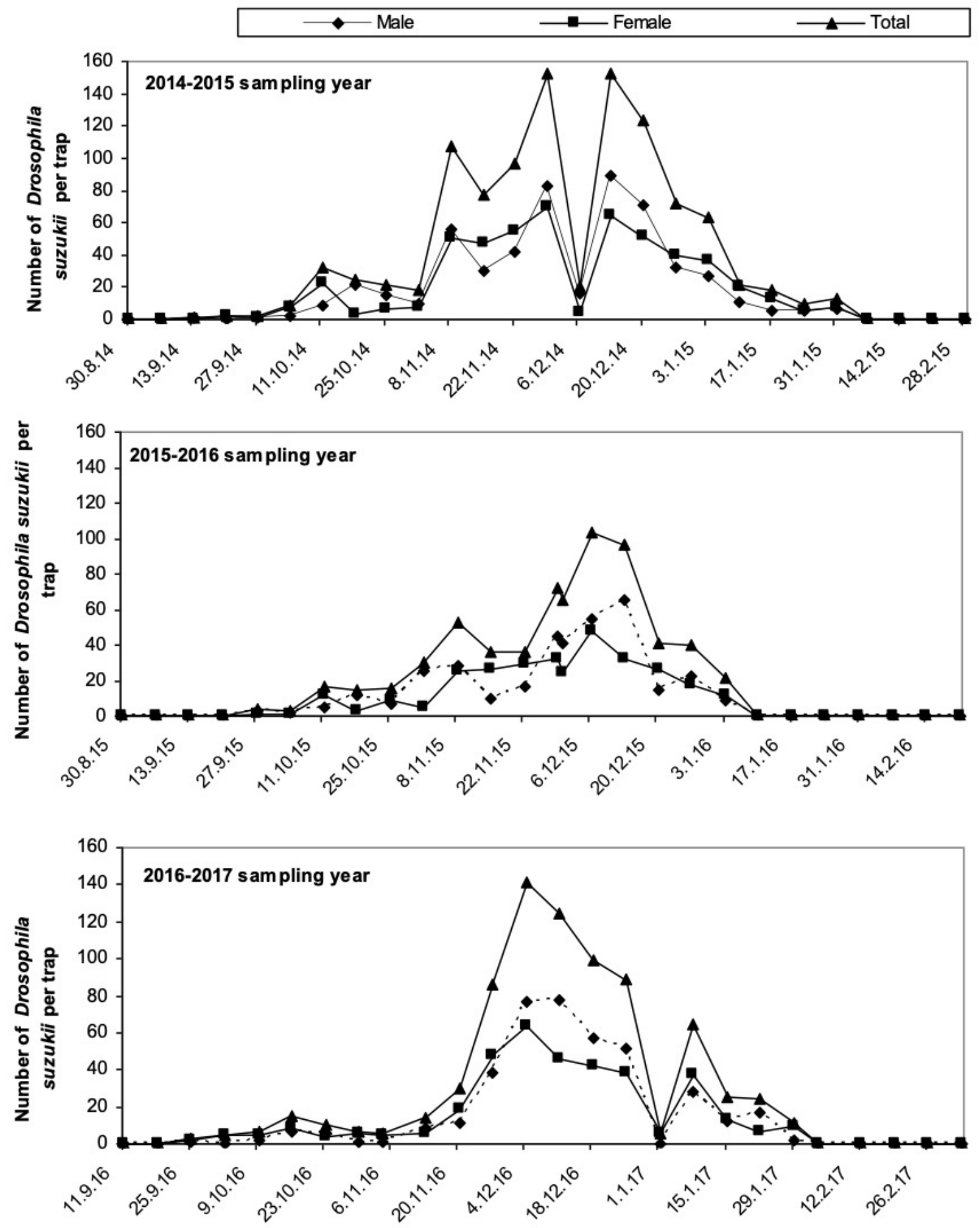

Sampling date

Figure 2. The population development of Drosophila suzukii in vineyards of Çanakkale Province in three growing seasons from 2014 to 2017. 
Based on the present study and literature reports it is concluded that $D$. suzukii is an important pest for fruit such as cherry, grape, plum and strawberry throughout the year, and that the pest infests both damaged and healthy fruit. In Çanakkale Province, the population of the pest started to develop in September, reaching its maximum in December and continuing until January. It was noted that they primarily preferred healthy fruit during their development period, but that they can develop in damaged fruit when the availability of healthy fruit decreased.

\section{References}

Anonymous, 2012. The Survey Instructions of Guidelines Manuel Book. Republic of Turkey Ministry of Agriculture and Forestry, Ankara, $87 \mathrm{pp}$.

Anonymous, 2017. TÜiK, Turkish Statistical Institute. (Web page: http://tuik.gov.tr) (Date accessed: 07.06.2017).

Baser, N., O. Broutou, V. Verrastro, F. Porcelli, C. Loriatti, G. Anfora, V. Mazzoni \& M. V. Rossi Stacconi, 2018. Susceptibility of table grape varieties grown in South-eastern Italy to Drosophila suzukii. Journal of Applied Entomology, 142: 465-472.

Baser, N., M. Quantar, O. Broutou, F. Lamaj, V. Verrastro \& F. Porcelli, 2015. First finding of Drosophila suzukii (Matsumura) (Diptera: Drosophilidae) in Apulia, Italy, and its population dynamics throughout the year. Fruits, 70 (4): 225-230.

Beers, E. H., R. A. Van Steenwyk, P. W. Shearer, W. W. Coates \& J. A. Grant, 2011. Development of Drosophila suzukii insecticide management programs for sweet cherry in the western United States. Pest Management Sciences, 67 (11): 1386-1395.

Bolda, M. P., R. E. Goodhue \& F. G. Zalom, 2010. Spotted wing drosophila: potential economic impact of newly established pest. Agricultural Resource Economic Update, University of California Giannini Foundation Agricultural Economic, 13 (3): 5-8.

Bruck, D. J., M. Bolda, L. Tanigoshi, J. Klick \& J. Kleiber, 2011. Laboratory and field comparisons of insecticides to reduce infestation of Drosophila suzukii in berry crops. Pest Management Sciences, 67: 1375-1385.

Calabria, G., J. Máca, G. Bächli, L. Serra \& M. Pascual, 2012. First records of the potential pest species Drosophila suzukii (Diptera: Drosophilidae) in Europe. Journal of Applied Entomology, 136: 139-147.

Cini, A., G. Anfora, L. A. Escudero-Colomar, A. Grassi, U. Santosuosso, G. Seljak \& A. Papini, 2014. Racking the invasion of the alien fruit pest Drosophila suzukii in Europe. Journal of Pest Sciences, 87: 559-566.

Cini, A., C. Loriatti \& G. Anfora, 2012. A review of the invasion of Drosophila suzukii in Europe and a draft research agenda for integrated pest management. Bulletin of Insectology, 65: 149-160.

Depra, M., J. L. Poppe, H. J. Schmits, C. Toni \& V. L. S. Valente, 2014. The first records of the Drosophila suzukii invasive pest in the South American continent. Journal of Pest Sciences, 87: 379-383.

Emiljanowicz, L. M., G. D. Ryan, A. Langille \& J. Newman, 2014. Development, reproductive output and population growth of the fruit fly pest Drosophila suzukii (Diptera: Drosophilidae) on artificial diet. Journal of Economic Entomology, 107 (4): 1392-1398.

Goodhue, R. E., M. Bolda, D. Farnsworth, J. C. Williams \& F. G. Zalom, 2011. Spotted wing drosophila infestation of California strawberries and raspberries: Economic analysis of potential revenue losses and control costs. Pest Management Sciences, 67: 1396-1402.

Hauser, M., 2011. A historic account of the invasion of Drosophila suzukii (Matsumura) (Diptera: Drosophilidae) in the continental United States with remarks on their identification. Pest Management Science, 67: 1352-1357.

Ioriatti, G., V. Walton, D. Dalton, G. Anfora, A. Grassi, S. Maistri \& V. Mazzoni, 2015. Drosophila suzukii (Diptera: Drosophilidae) and its potential impact to wine grapes during harvest in two cool climate wine grape production regions. Journal of Economic Entomology, 108: 1148-1155.

Kanzawa, T., 1939. Studies on Drosophila suzukii Mats., Yamanashi agricultural experimental station. Kofu. Review of Applied Entomology, 29: 622.

Kasap, İ. \& E. Özdamar, 2017. "New invasive pest in Turkey Drosophila suzukii (Matsumura) (Spotted Wing Drosophila, SWD), 351". ISEEP-2017 VIII. International Symposium on Ecology and Environmental Problems (4-7 October 2017, Çanakkale, Turkey), 388 pp. 
Lee, J. C., D. J. Bruck, A. J. Dreves, C. Ioriatti, H. Vogt \& P. Baufeld, 2011. In focus: Spotted wing drosophila Drosophila suzukii, across perspectives. Pest Managements Sciences, 67: 1349-1351.

Ögür, E., L. Ünlü \& F. Canbulat, 2018. New record for spotted wing Drosophila, Drosophila suzukii (Matsumura, 1931) (Diptera: Drosophilidae) in Karaman, Central Anatolia. Agricultural \& Forestry, 64 (1): 189-197.

Önder, B. S., U. Ünal, A. Orhan, G. Tozlu \& R. Aslantaş, 2016. "Anadolu'da yeni bir istilacı meyve zararlısı olan Drosophila suzuki'nin kolonizasyon senaryosu, 36”. 23. Ulusal Biyoloji Kongresi (5-9 September 2016 Gaziantep, Turkey), 472 pp.

Orhan, A., R. Aslantaş, B. S. Önder \& G. Tozlu, 2016. First record of the invasive vineyard fly Drosophila suzukii (Matsumura) (Diptera: Drosophilidae) from eastern Turkey. Turkish Journal of Zoology, 40: 290-293.

Özdamar, E. \& İ. Kasap, 2017. "Monitoring of Drosophila suzukii population Growth on grape orchards in Çanakkale region, 350". VIII. International Symposium on Ecology and Environmental Problems (4-7 October 2017, Çanakkale, Turkey), $388 \mathrm{pp}$.

Raspi, A., A. Canale, R. Canovai, B. Conti, A. Loni \& F. Strumia, 2011. Insetti delle aree protette del comune di San Giuliano Terme. Pisa, Italy: Felici Editore, San Giuliano Terme (in Italian).

Stewart, T. J., X. G. Wang, A. Molinar \& K. M. Daane, 2014. Factors limiting peach as a potential host for Drosophila suzukii (Diptera: Drosophilidae). Journal of Economic Entomology, 107: 1771-1779.

Tozlu, G., R. Aslantaş, B. S. Önder \& A. Orhan, 2016. "Türkiye için önemli bir meyve zararlısı: İstilacı tür Drosophila suzukii, 260". Turkey VI. Plant Protection Congress with International Participations (5-8 September 2016 Konya, Turkey), $938 \mathrm{pp}$.

Walsh, D. B., M. P. Bolda, R. E. Goodhue, A. J. Dreves, J. Lee, D. J. Bruck, V. M. Walton, S. D. O’Neal \& F. G. Zalom, 2010. Drosophila suzukii (Diptera: Drosophilidae): invasive pest of ripening soft fruit expanding its geographic range and damage potential. Journal Integrated Pest Management, 2: G1-G7.

Yu, D., F. G. Zalom \& K. A. Hamby, 2013. Host status and odor response of Drosophila suzukii (Diptera: Drosophilidae) to figs and mulberries. Journal of Economic Entomology, 106 (4): 1932-1937. 